\title{
Analysis of Recent Four Years' Cross-Matching Tests of One Commercial Laboratory
}

Dong Hee Seo, Mi Young Park, and Jeong Ryull Kwak

LabGenomics Clinical Laboratories, Seongnam, Korea

Corresponding author:

Dong Hee Seo

LabGenomics Clinical

Laboratories, 700

Daewangpangyo-ro, Bundang-

gu, Seongnam 13488, Korea

Tel: +82-31-628-0730

Fax: +82-31-628-0701

E-mail: seo2023@nate.com

pISSN: 2384-2458

elSSN: 2288-7261

\begin{abstract}
The cross-matching test, an essential pre-transfusion test, is usually performed using only a segment of a blood bag and a recipient's blood sample at a commercial laboratory. We analyzed cross-matching test results obtained at LabGenomics laboratory, client of which were mainly small- and medium-sized medical clinics. Data for a total of 12,902 cross-matching tests referred from January 2012 to December 2015 were analyzed for incompatibility in the results and trends based on the distribution of medical clinics. Medical clinics were categorized as nursing home, obstetrics and gynecology, plastic surgery, dental clinic, orthopedic surgery, and others. Incompatible results were observed for 35 cases (1.09\%) in 2012, 22 cases $(0.68 \%)$ in 2013, 31 cases (1.02\%) in 2014, and 41 cases (1.20\%) in 2015. Overall, $55.4 \%$ of referrals came from a nursing home, $6.4 \%$ from obstetrics and gynecology, $4.4 \%$ from plastic surgery, $20.0 \%$ from dental clinic, $5.9 \%$ from orthopedic surgery, and $7.9 \%$ from others. Further studies are required to evaluate the efficacy of cross-matching test results and its relationship with transfusion requirements.
\end{abstract}

(J Lab Med Qual Assur 2016;38:249-252)

Key Words: Transfusion, Cross-match, Nursing home, Commercial laboratory

Received May 16, 2016, Revision received August 23, 2016, Accepted August 29, 2016
용혈성 수혈부작용 예방을 위하여 수혈 예정 혈액의 적혈구 와 환자의 혈청을 반응시켜보는 교차시험은 수혈 전 검사로 필 수적인 검사이다. 교차시험은 수혈 혈액과 수혈자의 $\mathrm{ABO}$ 혈 액형을 재확인하고, 수혈 혈액의 적혈구에 존재하는 항원들에 대한, 환자의 혈청에 있는 비예기항체들을 검출하는 데 그 목 적이 있다[1]. 의료기관에서의 교차시험은 수혈용 혈액이 혈 액은행에 보관되어 있는 상태에서 수혈용 혈액과 환자의 검체 를 이용해 이루어지고 있지만, 수탁검사기관에서는 주로 수혈 될 혈액의 관분절(segment)과 환자 검체를 이용해 교차시험 이 이루어지고 있다.

2013년도에 대한적십자사 혈액원으로부터 1단위 이상의 혈 액을 공급받은 의료기관은 2,726 개소로 파악되었고, 이 중 연 간 혈액제제 공급량이 1,000 단위 이하인 의료기관이 2,391 개
소로 전체의 $87.7 \%$ 를 차지하고 있었다[2]. 대한임상검사정 도관리협회에서 시행하고 있는 혈액은행분과 신빙도조사사업 중 교차시험검사 외부정도관리에 참여하고 있는 기관은 2014 년도에 486기관으로 확인되어 수혈용 혈액을 사용하는 의료기 관 중 약 2,000 여 의료기관은 교차시험을 자체적으로 실시하 지 않는 것으로 추정된다[3]. 또한 의원급 의료기관에서 자체 적으로 교차시험을 시행하기 위해서는 임상병리사 등 검사 인 력이 필요하다. 이러한 연유로 국내 중소규모 의료기관에서의 수혈 전 검사가 불충분하게 이루어지고 있을 가능성이 있다는 우려가 있다. 이에 중소규모 의료기관의 검체를 주로 검사하는 랩지노믹스 검사센터에서 이루어지고 있는 교차시험 현황을 조사해 보았다.

2012년 1월부터 2015년 12월까지 4년 동안 본 검사센터에 


\section{Journal of LABORATORY MEDICINE and QUALITY ASSURANCE}

\section{Dong Hee Seo et al • Analysis of Recent 4 Years' Cross-Matching Tests}

의뢰된 총 12,902 건의 교차시험 의뢰건을 대상으로 하였다. 랩지노믹스 검사센터에서는 시험관법으로 $\mathrm{ABO}$ 혈액형을 확 인하고 있으며, 원주응집법을 사용하는 Ortho BioVue AHG cassette (Ortho-Clinical Diagnostics, Raritan, NJ, USA)으 로 교차시험을 시행하고 있다. 교차시험 의뢰용 수혈용 혈액 의 검체는 혈액번호와 검체 바코드가 부착된 관분절을 의료기 관에서 보내어 준다(Fig. 1). 연도별 교차시험 부적합률과 검 사 의뢰 의료기관의 분포를 조사하였다. 의료기관 분포는 요양 병원, 산부인과, 성형외과, 치과, 정형외과, 기타 의료기관으로 분류하여 조사하였다.

본 검사센터에 2012년도에는 62 개 의료기관으로부터 3,213 건, 2013년도에는 72개 의료기관으로부터 3,227건, 2014년도 에는 74 개 의료기관으로부터 3,044건, 2015년에는 80개 의료 기관으로부터 3,418건의 교차시험이 의뢰되었다. 2012년도 에 교차시험을 의뢰한 의료기관의 분포는 요양병원이 1,380 건, 산부인과 204 건, 성형외과 223 건, 치과 1,153 건, 정형외 과 165 건, 기타 의료기관이 88건이었다. 2013년도와 2014년 도의 의료기관 분포는 요양병원 1,647 건과 1,835 건, 산부인 과 248 건과 231 건, 성형외과 184 건과 104 건 등이었다(Table 1). 2015 년에는 요양병원이 $66.8 \%$, 산부인과 $4.1 \%$, 성형외과 $1.8 \%$, 치과 $6.1 \%$, 정형외과 $5.1 \%$, 기타 의료기관이 $16.1 \%$ 를 차지하고 있었다. 2012년부터 2015년까지 4년 전체 교차시 험에 대해서는 요양병원이 $55.4 \%$, 산부인과 $6.4 \%$, 성형외과 $4.4 \%$, 치과 $20.0 \%$, 정형외과 $5.9 \%$, 기타 의료기관이 $7.9 \%$ 를 의뢰하고 있었다(Table 1).

교차시험 부적합 건수는 2012년 35건(1.09\%), 2013년 22건 (0.68\%), 2014년 31건(1.02\%) 그리고 2015년 41건(1.20\%) 으로 총 129 건(1.00\%)이었다. 총 129 건의 교차시험 부적합 중 80 건이 요양병원, 19 건이 산부인과, 3 건이 성형외과, 10 건 이 치과, 3 건이 정형외과, 14 건이 기타 의료기관에서 관찰되었
다. 의료기관별 교차시험 의뢰건 대비 부적합 비율은 요양기관 이 $1.1 \%$, 산부인과 $2.3 \%$, 성형외과 $0.5 \%$, 치과 $0.4 \%$, 정형외 과 $0.4 \%$, 기타 의료기관 $1.4 \%$ 를 보였다.

최근 4년간 본 검사센터의 교차시험 검사건수는 연간 약 3,000 건 수준에서 큰 변화를 보이고 있지 않았다. 교차시험 부 적합률은 $1.00 \%(0.68 \%-1.20 \%)$ 였다. 현재까지 국내 교차시 험 부적합률에 대해 보고된 바는 없다. 이는 의료기관 혈액은 행에서는 비예기항체 선별검사를 시행한 후 교차시험을 검사 하는 순서로 수혈 전 검사가 진행되어 대부분의 경우에 비예기 항체 양성률이 보고되기 때문이다. 본 검사센터와 동일한 교차 시험 시약을 사용한 $\operatorname{Lim}$ 등 $[4]$ 은 $1.3 \%$ 의 비예기항체 빈도를 보고하였다. 원주응집법을 사용하지만 시약의 제조사가 다른 연구에서는 $0.5 \%$ [5], 0.54\% [6]의 비예기항체 양성률을 보 고하였다. 비예기항체 선별검사용 시약의 종류에 따라 민감도 와 특이도에서 약간의 차이를 보이며, 본 검사센터에서 사용하 는 시약이 다른 원주응집법 시약보다 약간은 낮은 민감도를 보

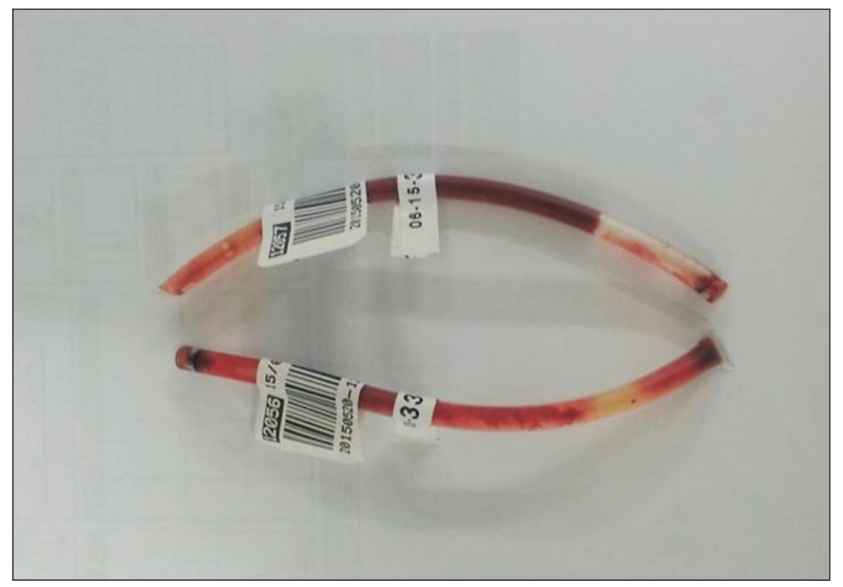

Fig. 1. Blood bag segments for cross-matching tests.

Table 1. Numbers of cross-matching tests and incompatible results by referral type

\begin{tabular}{|c|c|c|c|c|c|c|c|}
\hline Year & Nursing home & $\begin{array}{c}\text { Obstetrics and } \\
\text { gynecology }\end{array}$ & Plastic surgery & Dental clinics & $\begin{array}{c}\text { Orthopedic } \\
\text { surgery }\end{array}$ & Others & Total \\
\hline 2012 & $1,380(43.0)$ & $204(6.4)$ & $223(6.9)$ & 1,153 (35.9) & $165(5.1)$ & $88(2.7)$ & $3,213(100.0)$ \\
\hline 2014 & $1,835(60.3)$ & $231(7.6)$ & $104(3.4)$ & $471(15.5)$ & $204(6.7)$ & $199(6.5)$ & $3,044(100.0)$ \\
\hline 2015 & $2,283(66.8)$ & $140(4.1)$ & $60(1.8)$ & $209(6.1)$ & $176(5.1)$ & $550(16.1)$ & $3,418(100.0)$ \\
\hline Incompatible & $80(1.1)^{*}$ & $19(2.3)$ & $3(0.5)$ & $10(0.4)$ & $3(0.4)$ & $14(1.4)$ & $129(1.0)$ \\
\hline
\end{tabular}

Values are presented as number (\%).

*Percentage of overall incompatible results. 


\title{
Journal of LABORATORY MEDICINE and QUALITY ASSURANCE
}

\author{
Dong Hee Seo et al • Analysis of Recent 4 Years' Cross-Matching Tests
}

인다는 보고도 있다[7]. 본 조사의 교차시험 부적합률과 기존 의 비예기항체 양성률을 직접 비교하기에는 어려움이 있지만, 교차시험의 부적합이 대부분 비예기항체의 존재에 기인한다 고 가정한다면 기존의 연구결과와 큰 차이를 보이지 않는 것으 로 여겨진다. 산부인과의 부적합비율이 $2.3 \%$ 로 다른 의료기 관보다 높게 나왔는데, 임신 등의 면역학적 노출에 의해 여성 에서 비예기항체의 생성 가능성이 높기 때문인 것으로 여겨진 다.

본 검사센터에 교차시험을 의뢰하는 의료기관 수는 2012 년 62개 기관에서 2015년 80개 기관으로 약간의 증가를 보였 다. 본 검사센터에 검사를 의뢰하는 의료기관은 전체적으로 약 2,800 기관으로, 이 중 약 $2.9 \%$ 의 의료기관이 교차시험을 의 뢰하는 것으로 조사되었다. 의료기관 종류를 보면 요양병원이 2013년부터 50\% 이상을 차지하고 있었고, 해마다 그 비율이 증가하고 있었다. 노인 환자를 돌보는 요양병원의 수혈 요구도 가 일반 의료기관보다는 높은 것으로 판단된다. 성형외과와 산 부인과는 $10 \%$ 미만을 차지하고 있었고, 성형외과와 산부인과 에서의 수혈요구도가 감소하고 있는 것으로 파악되었다. 2012 년도에 1,153 건의 교차시험을 의뢰한 치과는 양악수술을 시행 하는 두 곳의 치과의원의 검사 의뢰로 파악되었다. 이 두 치과 의원의 교차시험 의뢰건이 해마다 줄어들면서 2015 년도에는 치과가 차지하는 비율이 $6.1 \%$ 로 감소하였다. 이러한 교차시 험 의뢰 추세를 반영해보면 향후 본 센터에서는 요양병원의 교 차시험 비율이 증가할 것으로 예상되며, 성형외과와 치과의 교 차시험 의뢰건은 줄어들 것으로 생각된다.

관분절만으로 교차시험을 시행하는 경우 Fig. 1과 같이 혈액 번호 라벨과 검체 바코드가 동시에 부착되어 오는 경우는 교차 시험결과 통보와 의료기관의 수혈 업무 오류의 발생 가능성이 적다고 본다. 그러나 혈액번호 라벨만 부착되어 경우에는 동명 이인이 있는 경우 등에서 검사오류가 발생할 가능성이 있어서 검체 바코드 라벨 부착이 요구된다. 본 검사센터에 교차시험 오류에 대한 의료기관의 보고 건수는 없었지만 수혈 오류 가능 성에 대한 주의가 요구된다.

본 검사센터에 수탁검사를 의뢰하는 기관 중 약 $2.9 \%$ 의 의 료기관만이 교차시험을 의뢰하고 있어, 이것이 의료기관의 실
제 수혈 요구도를 정확히 반영하는지 아니면 수혈 전 검사 없 이 수혈이 이루어지고 있는지를 파악하기 위해서는 의료기관 과의 공동연구가 필요하다. 본 조사를 통해 요양병원의 교차시 험 의뢰건수가 증가하고 있음과 본 검사센터에 교차시험을 의 뢰하는 의료기관 수가 많지 않음을 확인할 수 있었다.

\section{REFERENCES}

1. Han KS, Park KU, Song EY. Transfusion medicine. 4th ed. Seoul: Korea Medical Book Publisher, 2014.

2. Oh DJ. Safe issues of blood supplying hospitals. Proceedings of joint symposium of Korean Society of Blood Transfusion and Korea Centers for Disease Control and Prevention; 2014 Nov 28; Seoul, Korea. Seoul: Korean Society of Blood Transfusion, 2014:15-22.

3. Lim YA, Oh JS, Kwon SW, Kwon KC, Kim SY, Park KU, et al. Annual report on the external quality assessment scheme for blood blank tests in Korea (2014). J Lab Med Qual Assur 2015;37:47-55.

4. Lim G, Park KS, Park TS, Lee HJ, Suh JT, Park SY. The frequency and distribution of unexpected antibodies in transfusion candidates with the use of the Ortho BioVue System: recent four year experience. Korean J Blood Transfus 2009;20:23-31.

5. Ahn JY. Frequency of detection of unexpected antibodies in transfusion candidates at a secondary hospital in Gyeongbuk Province. Korean J Blood Transfus 2011;22: 231-6.

6. Jung TK, Lee NY, Bae HG, Kwon EH, Park SH, Suh JS. Unexpected antibody positivity with the use of the LISS/ Coombs gel test. Korean J Clin Pathol 2001;21:422-5.

7. Park JS, Park CM, Chang HE, Kim MJ, Park KU, Song J, et al. Evaluation of the performance of the DG gel test for unexpected antibody screening and identification. Korean J Blood Transfus 2008;19:49-56. 


\section{일개 수탁검사기관의 최근 4년간 교차시험 현황분석 서동희 • 박미영 • 곽정율 \\ 랩지노믹스 검사센터}

교차시험은 필수적인 수혈 전 검사로 수탁검사기관에서는 주로 수혈될 혈액의 관분절(segment)과 환자 검체를 이용해 교차시험이 이루어지고 있다. 중소규모 의료기관의 검체를 주로 검사하는 랩지노 믹스 검사센터에서 이루어지고 있는 교차시험 현황을 조사해 보았다. 2012년 1월부터 2015년 12월 까지 4년 동안 본 검사센터에 의뢰된 총 12,902건의 교차시험 의뢰건을 대상으로 하여 연도별 교차 시험 부적합률과 검사 의뢰 의료기관의 분포를 조사하였다. 의료기관 분포는 요양병원, 산부인과, 성 형외과, 치과, 정형외과, 기타 의료기관으로 분류하여 조사하였다. 교차시험 부적합 건수는 2012년

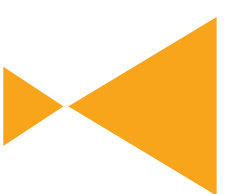

Journal of

LABORATORY MEDICINE and

QUALITY ASSURANCE 35건(1.09\%), 2013년 22건(0.68\%), 2014년 31건(1.02\%), 그리고 2015년 41건(1.20\%)을 보였 다. 4년 전체 교차시험에 대해서 요양병원이 $55.4 \%$, 산부인과 $6.4 \%$, 성형외과 $4.4 \%$, 치과 $20.0 \%$, 정형외과 $5.9 \%$, 기타 의료기관이 $7.9 \%$ 를 의뢰하고 있었다. 의료기관의 실제 수혈 및 교차시험 요구 도를 파악하기 위해서는 추가적인 연구가 필요하다.

(J Lab Med Qual Assur 2016;38:249-252) 